
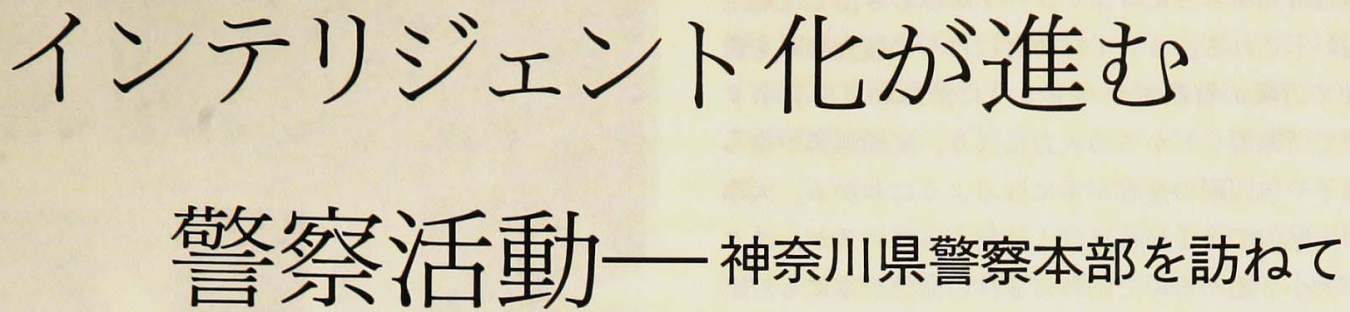

神奈川県警察本部の新庁舎で最新方式の通信指令, 交通管制がスタートして間もなく2 年。寸秒を争う警 察活動の大脳として, 県下の警察署や派出所, パトカ
一など手足を存分に㗢かせている。他府県の警察関係 者や企業のハイテク担当者の視察も多く，一般県民や 学校の社会科見学で大したにぎわいぶりである。
1992 年春完成した神奈川県警察本部の新庁舎

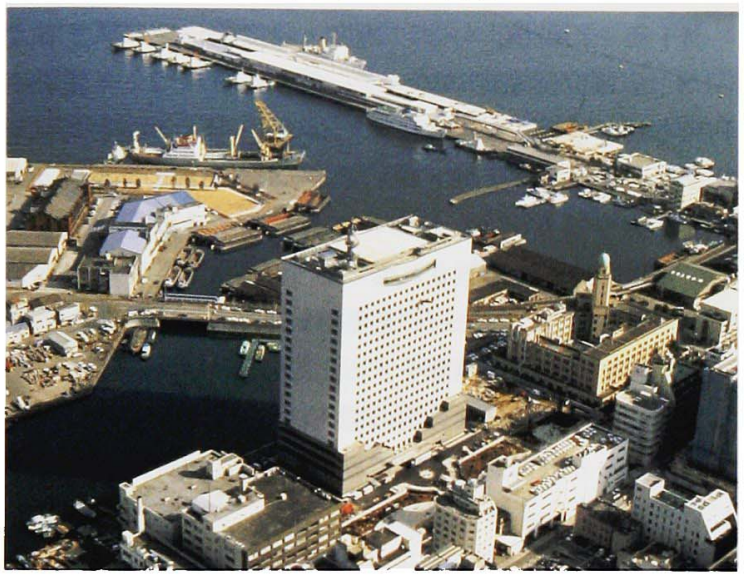

- 110 番を迅速処理する中枢神経

「はい 110 番, 警察です。何がありましたか」一広 くて天井の高い通信指令室の左すみから応答の声が聞こえ る。一般住民から通報が飛び込んできたところだ。その 110 番受付台の右上で円筒形の標識ランプが緑色からオレ ンジ色に変わって,「入電中」を全室に知らせる。聞き取 りながらワープロ方式で打ち込んだ通報内容は, 無線指令 台のモニタで即座に読み取れる。ひったくり事件が起こっ たらしい。「すぐパトカーを派遣します」

無線指令台では, 110 番受付台で確定した通報場所のマ ーキング地図と 110 番の通報内容が画面表示される。その 隣の画面には，付近にいるパトカーの位置を示す地図が現 われて扔り，その両方を見比べながら「神奈川本部から横 浜 1 号, ○○へ向かえ」とパトカーに指令を出す。

神奈川県下の 110 番通報はすべて, ここ県警本部の 110 番受付台に入電する。1 日平均約 2,000 件。東京の警視庁 についで全国で 2 番目に多い。凶悪事件, 交通事故のほ
か，暴走族の騒音苦情からトラブル相談まで内容も様々 だ。このうち警察官の対応が必要なのは約 1,300 件。パト カーや所轄署への指令はすべて無線指令台から出される。

110 番受付台 20 台, 無線指令台 10 台のほか 110 番監督 台, 総合指令台, 指揮指令台が並んだ風景は, まったく壮 観だ。ここは 17 階だが 18 階まで吹き抜けになっており， フロアの前方には映画館のように大スクリーンが広がって いる。といっても 1 面ではなく 4 面もある。中央に 200 イ ンチが 2 面，その両わきに 110 インチが各 1 面。いずれも 超高精細スクリーンで，指令台のスイッチによって事件現 場の地図, 全パトカーの所在地図, ヘリコプターからの映 像, コンピュータ画像, 放送中のテレビ画面, ビデオ映 像，文字情報など何でも映し出すことができる。

大型スクリーンが真価を発揮するのは, 強盗やひき逃げ など凶悪事件が発生して緊急配備を指令する時だ。事件現

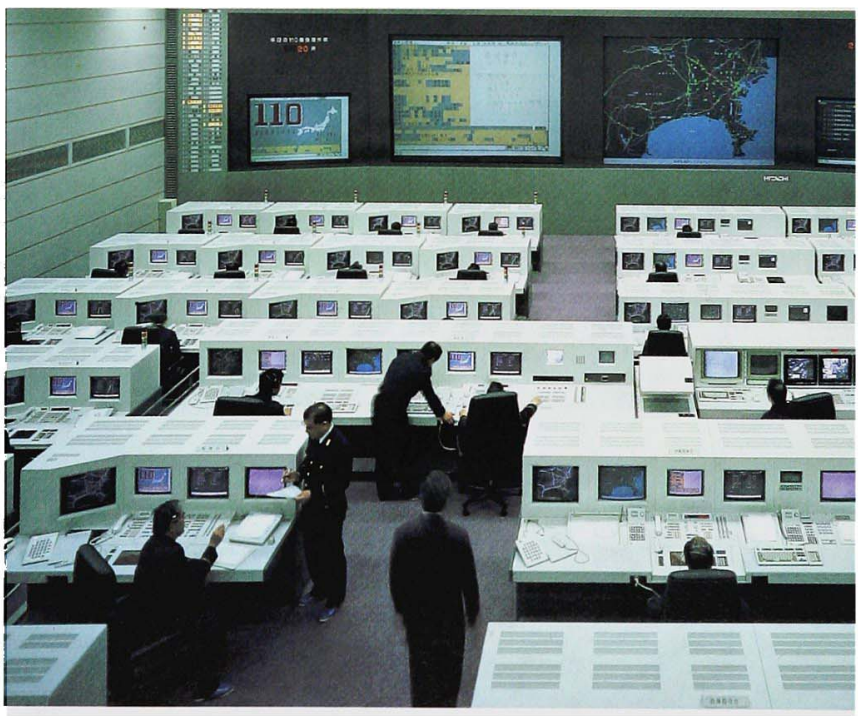

2 階分吸き拔けになった映画館のような通信指令室 


\section{十見 百聞}

場の地図情報が大きく映し出され, 犯人の逃走方向, 逃走 手段, 経過時間をもとにコンピュータがはじき出した逃走 可能範囲が示される。そこで指揮官は自らの捜查経験を重 ね合わせて近隣の警察署やパトカーに緊急動員を発令す る。やがて所轄署などからの入力により, 配備態勢が整っ ていく様子や包囲網の全容が手に取るようにわかる。大事 件は神奈川県内では 1 日にほぼ 1 件起こっているが，スク リーンが大小 2 組あるので同時に 2 件の緊急事案にも対応 できる。いまや同県警では, 犯人の早期逮捕, 被害者の保 護, 犯行の拡大防止に欠かせないシステムとなっている。

110 番通報を聞きながら住所を書き留めると, $2 \sim 3$ 秒後 にはもう受付台の画面にベクトル地図が現われている。住 所番地のほか, 幼稚園や郵便局, マンション, 商店など主 要な建物やバス停, 電話ボックスの名前を文字で入力する だけで地図画像が呼び出され, 拡大・縮小も自由自在。幅 3.3 メトル以上の道がすべて描き出され, クローズアッ プすれば各棟の居住者の名前まで読み取れる。

\section{•支援設備の充実に県費を投入}

指令台の地図画面にパトカーの現在位置が図示されるよ うになってから, 初動活動が迅速, 的確に行えるようにな つた。それを可能にしたのが高精度の無線自動車動態表示 (カーロケータ) システムだ。いまどの車がどこにいて, どの方向に進んでいるか, 何をやっているかがひと目で分 かる。カーロケー夕装置はパトカーなど 300 台余に搭載さ れており，県下をくまなく走っている。

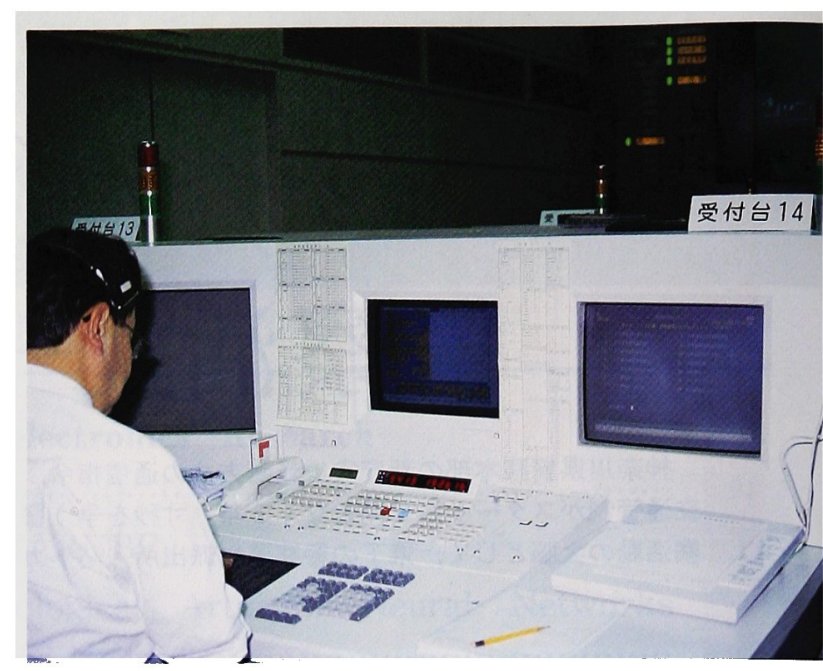

通信指令室の 110 番受付台

パトカーの位置,つまり緯度・経度の決定に人工衛星 GPS (広域位置標定システム) から送られてくる電波が 利用されている。さらに光ファイバジャイロが進行方向を 検出し, 車速センサがトランスミッション部の回転数から 走行距離を割り出す。しかしこれだけでは誤差が出るの で, 警察署などに設置されているサインポストから位置情 報を受信して, パトカーに搭載されたコンピュータが総合 的に地図マッチング処理をする。こうして求められた正確 な現在位置のデータは専用の電波に乗せられ, 警察署など に設置した分散受信局を経て専用の電話回線で通信指令室 に送られている。

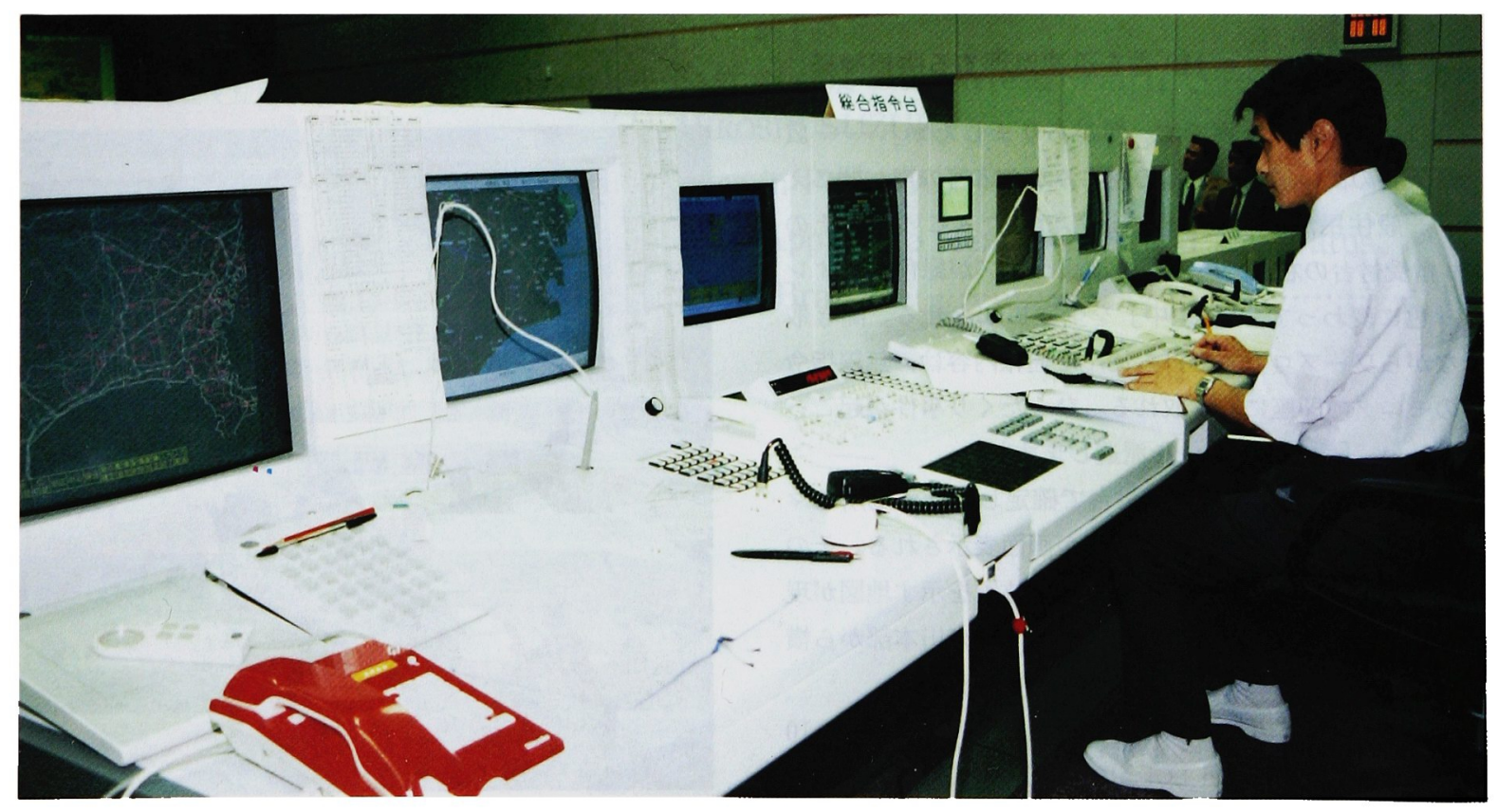

通信指令の総合指令台 


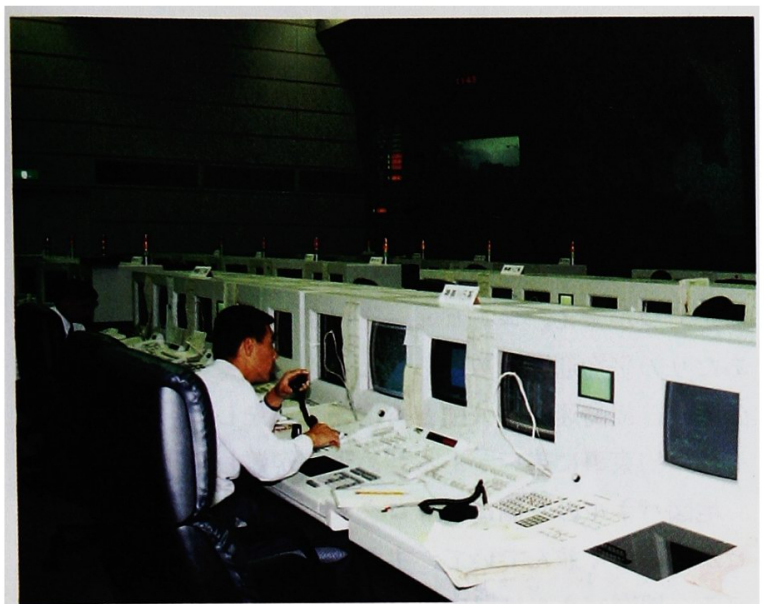

無線指令台

地図の上では，パトカーは三角形だ。とがった先が進行 方向を表わし，300メートル走るごとに位置がぼんぽんと 移っていく。ただし渋滞に巻き込まれたときは，2 分間隔 で表示される。また三角形の色によって普通のパトロール か, 本部からの指令に基づく活動か, 派出所に立ち寄り中 かが読み取れる。

県下には警察署が 51 あるが， 5 ブロックに分けて指令 が出される。もちろん大事件が発生したときは, 全県いっ せいに緊急配備の指令を出す。将来はパトカーの位置だけ でなく, 警察官ひとりひとりの現在位置をキャッチした い, という要望も出されているという。

この通信指令システムは 1992 年 5 月から稼働している が，ユーザ側の警察官が中心になって立案を開始したの は，県警本部の新庁舎完成より 5 年以上も前のことだ。す でに入っている各種のコンピュータや装置を生かしながら
LAN（組織内ネットワーク）でつなぎ，広範囲にわたる リアルタイム処理を模索した。建物の電源や空調の必要容 量についても頭を悩ませたという。情報処理の重要部分は 二重化して階層形集中・分散システムで構成されており, 無停電電源装置 (CVCF, バッテリー) で万一の停電にも 備えている。

200 インチの大スクリーンの据え付けも大変だった。大 きすぎるので建物を建築している最中に搬入した。かなり の摇れにも耐えられるように浮かしてあるので，巨大地震 でも壊れる心配はまずないという。ただ投射管の方は 1 万 時間で輝度が半減するので，絶えず更新しなければならな い。

この通信指令室には，もちろん昼夜の区別などない。と くに忙しいのは金曜日の夕方 6 時ごろから深夜の 2 時ごろ まで。土, 日の夜も暴走族による騒音苦情が殺到する。勤 務員の当直は 3 チームで回している。パトカー乗務の経験 者が中心で, そっくり同じ装置を備えた訓練室で機器や画 面の操作を習得してから配置につく。

110 番を受ける装置, 無線で指令する装置など基本的な 警察の通信施設は国費で整備することになっているが, 力 ーロケータシステム, 大型スクリーンなど支援的な設備は 各県の予算を使って特徵を持たせることができる。神奈川 県警のカーロケータや地図情報はとくにハイテク化が進ん でおり，文字入力はワープロだけでなく手書きでもでき る。ここのコンピュータシステムは, 現時点では日本で一 番新しい。すでに埼玉, 宮城, 大阪, 滋賀, 沖縄の各府県 警も新しいシステムを採り入れているが，これから北海 道, 茨城, 栃木, 京都, 兵庫, 愛知などにも広がろうとし ている。
交通管制センターの壁面の左側部

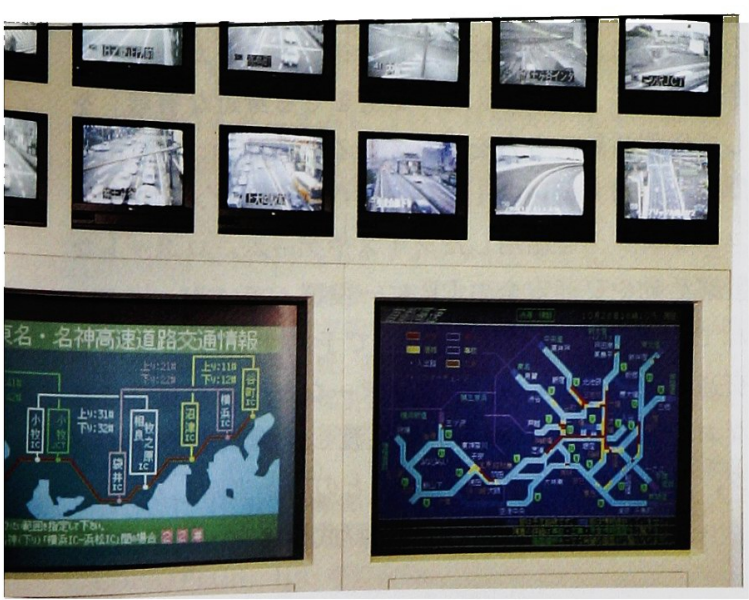

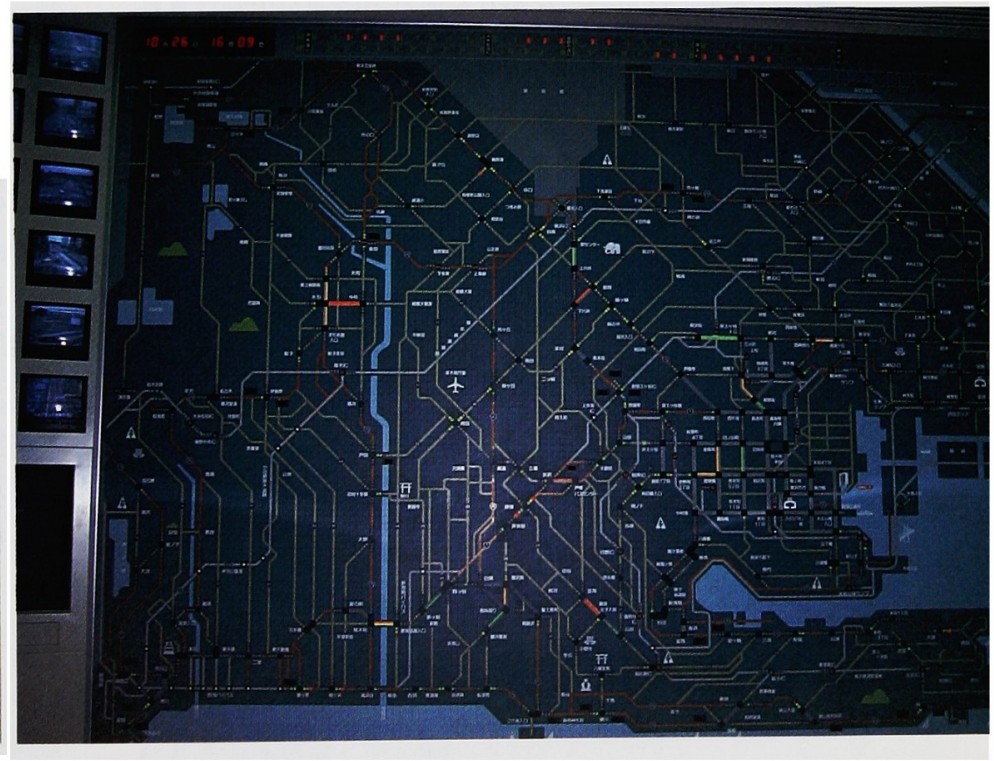




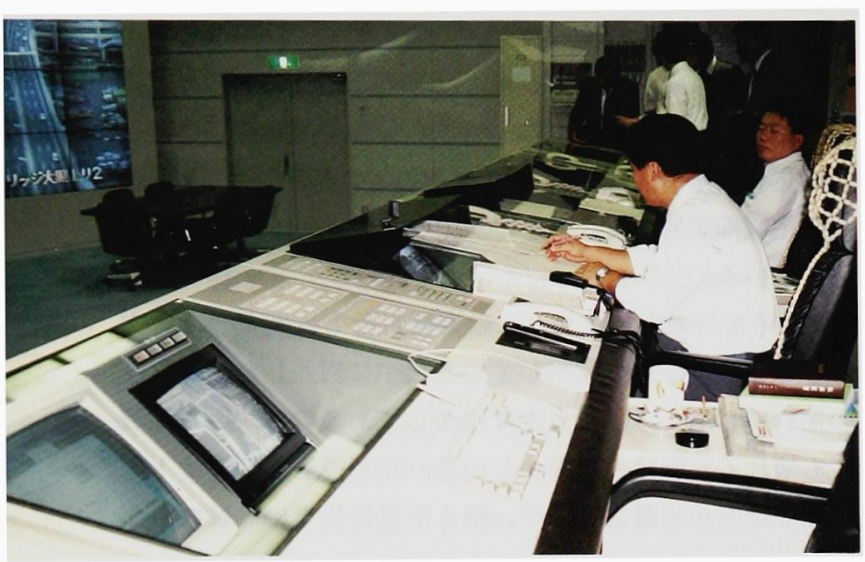

交通管制官たちの監視卓。ガラスごしに画面が見える

\section{•巨大な地図パネルで渋滞回避}

通信指令室と同じフロアに，やはり 2 階分を吹き抜けに した交通管制センターがある。階上の見学室に入ると，小 学生の団体を連れた女性の説明員が「ここは車がスムーズ に走れるようにしている扔部屋です」と明るい声を響かせ ていた。

管制官 5 人が座れる横長の監視卓があり，その正面の広 い壁面には県下の主要交差点ごとの渋滞状況を色で表示す る巨大な地図パネルが陣取っている。それぞれの監視卓に もテレピ画面とコンピュータの画面が組み込まれている が，机をおおうガラスの下にあるので，全体を机として広 く使うこともできる。この部屋のシステム一式がグッドデ ザイン賞を取ったそうだが，なるほど何もかもよく整って いる。ここも 3 交代 24 時間勤務。緊急時以外は管制官 2 人でこなしている。

地図パネルには車のつながりや流れの時速が色別にきれ

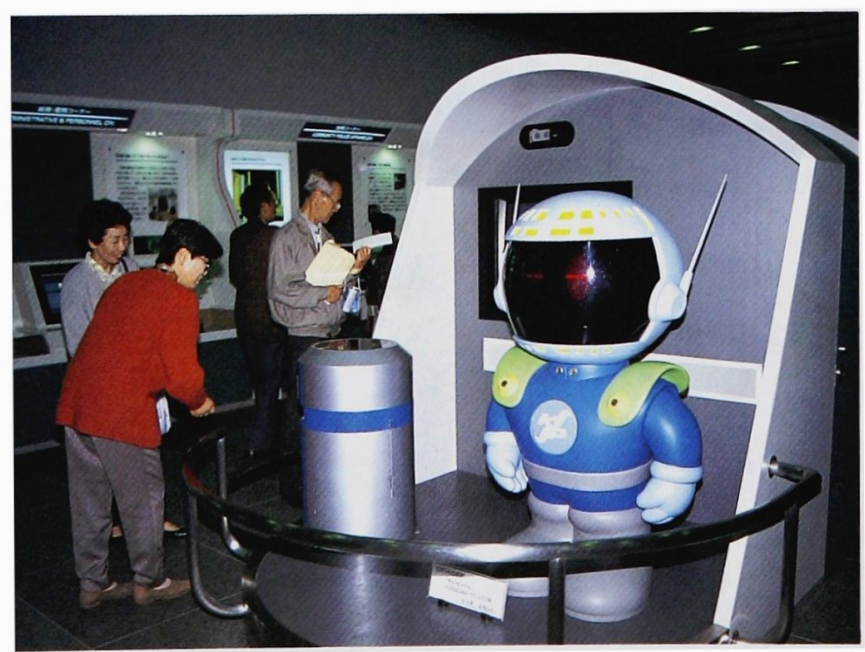

| 階の広報センター。ロポットKP君が庁舎の概要を説明してくれる
いに表示される。見学した平日の昼間は，横浜市内はかな り順調に車が流れており,むしろ東名高速「横浜インタ 一」の入口など周辺部の交差点に赤が灯って, 時速 15 キ ロ以下を示していた。横浜市内の車の量は膨大でも, 抜け 道がたくさんあるため混雑が少ないのである。

渋滞状況は, 道路の上から超音波を発射する車両感知器 などでつかまえ, コンピュータによる統計処理で単位時間 あたりの平均通過台数としてとらえる。警視庁や日本道路 公団, 首都高速道路公団とも情報交換をしているが, それ ぞれの約束事に違いがあるため調整が難しいようだ。

地図パネルの左側には「ロク・ロク」36台のモニタテレ ビが行儀よく並んでいて, 主要交差点の現状を映し出して いる。地図パネルは県内の交通渋滞を大づかみするのに適 してはいるが, 具体的な込み具合の把握はテレビ画像にか なわない。また交通事故が発生すればパトカーの助けを借 りて情報を収集する。これらの情報を総合判断して信号の 時間コントロールなどで渋滞を回避するのが, 管制官の腕 の振るいどころなのである。

交通管制センターにはもう一つ, ラジオやテレビへの情 報提供という任務もある。地図パネルと向き合った階上部 分に放送局や道路交通情報センターの小部屋が五つ並んで いて,リポーターたちはパネルや交差点の映像を見て渋滞 状況や空いている道を案内している。

地図パネルのデータや渋滞情報は, 通信指令室などでも 画面に呼び出して利用できる。それぞれのコンピュータ同 士でデータをやり取りして，お互いの地図の上に落とし込 めるようになっているのだ。パトカーが犯人を追いかける とき, コースの選択にも威力を発揮する。

この交通管制センターの設備は現時点では日本で最新を 誇っており, 信号の故障などもコンピュータ管理でかなり 分かるようになった。しかし信号機器の不具合や信号灯の 電球切れなどの異常把握は, まだ一般住民やドライバーか らの通報に頼らねばならない。トラブルの自動監視やシス テムの二重化による信頼性向上は今後に残された課題だ。

神奈川県警は「800万県民の安全を守る身近な警察」を めざして広報活動にも力を入れている。新庁舎（横浜市中 区海岸通 $2 丁$ 目 4 番) の 1 階に設けた「広報センター」で は, コンピュータを活用したクイズやゲーム，ロポットな どが警察活動や交通安全の PRに一役買っている。

だれでも電話（045-211-1212）で予約すれば通信指令 室, 交通管制センター, 広報センターなど庁内が見学でき る。なお, 20 階の長い廊下から見渡した横浜港やベイブ リッジ, ランドマークタワーは, ことのほか素晴しかった。 (取材・䅖本能涁, 塩野武男 /文 - 児玉浩憲) 